\title{
Learning McNamara's Lessons: How the War Powers Resolution Advances the Rule of Law
}

Peter M. Shane

Follow this and additional works at: https://scholarlycommons.law.case.edu/caselrev

Part of the Law Commons

\section{Recommended Citation}

Peter M. Shane, Learning McNamara's Lessons: How the War Powers Resolution Advances the Rule of Law, 47 Case W. Rsrv. L. Rev. 1281 (1997)

Available at: https://scholarlycommons.law.case.edu/caselrev/vol47/iss4/7

This Symposium is brought to you for free and open access by the Student Journals at Case Western Reserve University School of Law Scholarly Commons. It has been accepted for inclusion in Case Western Reserve Law Review by an authorized administrator of Case Western Reserve University School of Law Scholarly Commons. 


\title{
LEARNING MCNAMARA'S LESSONS: HOW THE WAR POWERS RESOLUTION ADVANCES THE RULE OF LAW
}

\author{
Peter M. Shane $e^{\dagger}$
}

The end of the Cold War has not diminished either political or scholarly interest in the allocation of governmental authority with respect to the use of military force. This is as it should be. Our post-Vietnam military forays into Iran, Lebanon, Grenada, Libya, Panama, Kuwait, Somalia, Haiti, and Bosnia amply demonstrate the continuing relevance of the debate. If anything, the reduced likelihood that local and regional military conflicts will erupt into superpower confrontation reduces the disincentive for the United States to deploy military force in the pursuit of discreet military and foreign policy objectives. Before the nation multiplies these experiences too many more times, thoughtful citizens ought consider the processes by which the government decides how our military forces should be used.

Nearly all recent academic articles on war powers-as well as two important recent books-focus on the ultimate question of law on this subject: Whom does the Constitution authorize to commit United States troops to military hostilities? There exist at least five different positions on this question:

John Hart Ely, ${ }^{2}$ Louis Fisher, ${ }^{3}$ and Jules Lobel $^{4}$ argue that

$\dagger$ Dean and Professor of Law, University of Pittsburgh College of Law. I would like to thank Gerald F. Burch for his able research assistance and my colleague Professor Jules Lobel for his generous willingness through our discussions to help strengthen an argument with which he disagrees.

1. See Peter M. Shane \& harold H. BrufF, Separation of Powers law 808-17, 839-44 (1996).

2. See JOHN HART ELY, WAR AND RESPONSIBILTTY: CONSTITUTIONAL LESSONS OF VIETNAM AND ITS AFTERMATH 3, 7 (1993).

3. See LOUIS FISHER, PRESIDENTIAL WAR POWER 11 (1995).

4. See Jules Lobel, "Little Wars" and the Constitution, 50 U. MiAMI L. REv. 61, 75 
the President is constitutionally empowered to deploy military force on his own initiative only in emergencies that preclude the pursuit of advance congressional authorization. They acknowledge no general presidential power to use military force to protect national security. Each specifically resists making a lawyerly leap from the President's universally recognized authority to repel sudden attacks to any broader power to respond unilaterally to national security threats wherever they may arise. ${ }^{5}$ These authors acknowledge a history of episodes in which Presidents have deployed military force unilaterally, but each insists either that such episodes are beyond the purview of the legal war powers debate or, if they are not, that a history of usurpatious practice cannot change our constitutional framework. ${ }^{6}$

At the other end of the spectrum, Robert Turner and John $\mathrm{Yoo}^{8}$ argue that the President enjoys unilateral authority to deploy United States forces in any situation other than the initiation on a major scale of offensive hostilities. Their positions echo official State Department doctrine articulated during the Vietnam War. Legal Advisor Leonard Meeker then argued that the President's responsibilities for foreign relations encompass "the power to deploy American forces abroad and commit them to military operations when the President deems such action necessary to maintain the security and defense of the United States." And, he left no

\section{(1995).}

5. See ELY, supra note 2, at 6-7; FISHER, supra note 3, at 6-8; Lobel, supra note 4, at 70.

6. See ELY, supra note 2, at 9-10; FISHER, supra note 3, at 191; Lobel, supra note 4 , at 71 .

7. See Robert F. Turner, War and the Forgotten Executive Power Clause of the Constitution: A Review Essay of John Hart Ely's War and Responsibility, 34-VA. J. INT'L L. 903, 906-10 (1994).

8. Actually, I am here understating Professor Yoo's conclusion as to the scope of presidential discretion in war making. Professor Yoo argues that the framers did not understand the declaration of war as an authorization for war, but rather as a declaration of a state of affairs between the United States and other nations intended to settle their "formal, legal relationship," and to justify different standards of American government behavior towards United States citizens with regard to their rights and duties. John C. Yoo, The Continuation of Politics By Other Means: The Original Understanding of War Powers, 84 CALIF. L. REV. 167, 245 (1996). Thus, under Professor Yoo's interpretation, the President never needs advance authorization for military initiative, but is subject always to congressional control through its funding powers. See id. at 295.

9. Leonard Meeker, The Legality of United States Participation in the Defense of Viet-Nam, 54 DEP'T ST. BULL. 474 (1976), reprinted in SHANE \& BRUFF, supra note 1, at 772 . 
doubt that pursuant to his argument the President's judgments in this respect were to be deemed legally authoritative:

The Constitution leaves to the President the judgment to determine whether the circumstances of a particular armed attack are so urgent and the potential consequences so threatening to the security of the United States that he should act formally without consulting the Congress. ${ }^{10}$

Between these two positions, at least three others exist in the literature. Acting Solicitor General Walter Dellinger, formerly assistant attorney general in charge of the Office of Legal Counsel, has argued for a Youngstown-like approach." Unlike Legal Advisor Meeker, Professor Dellinger concedes that Congress could, if it so desired, expressly constrain the President in exercising military force in most situations. ${ }^{12}$ Absent such constraints, however, whether the President may use armed forces in particular circumstances depends-à la Justice Jackson-on the nature, intent, and impact of the President's actions and on the full legislative context in which his initiative would go forward. ${ }^{13}$

Professor Peter Spiro has taken a more historically oriented approach, urging that long-standing historical practice has categorically confirmed both the requirement of congressional authorization for "the massive use of force against an enemy capable ... of marshaling substantial force," as well as the President's unilateral power to engage in small-scale "strike operations" in defense of American interests. ${ }^{14}$ Between these poles lie the problematic cases: open-ended deployments of United States troops in unstable or hostile environments. Presidents may initiate these deployments "for protective, humanitarian, or peacekeeping purposes,"15 but, because of their sometimes protracted nature, as well as their potential to create war, history confirms that they are subject to congressional regulation. ${ }^{16}$

10. Id.

11. See Youngstown Sheet \& Tube Co. v. Sawyer, 343 U.S. 579 (1952) (invalidating President Truman's seizure of steel mills during the Korean War).

12. See Walter Dellinger, After the Cold War: Presidential Power and the Use of Military Force, 50 U. MIAMI L. REv. 107, 113 (1995).

13. See id. at 116.

14. Peter J. Spiro, War Powers and the Sirens of Formalism, 68 N.Y.U. L. REv. 1338, 1348, 1352-53 (1993) (reviewing ELY, supra note 2).

15. Id. at 1354 .

16. See id. at $1354-55$. 
Professor Jane Stromseth, while pursuing interpretive methods akin to those of Professor Spiro, finds less play in the constitutional scheme for wholly discretionary presidential action. She finds historical confirmation for the President's powers to initiate peacetime deployments of troops for foreign policy purposes, as well as to engage in the limited use of force "to rescue American citizens abroad whose lives are in imminent danger." She disagrees with Professor Spiro's conclusion that the President is otherwise authorized to engage in "strike operations" for non-rescue purposes. ${ }^{18}$

The thoughtful scholarship offered in support of each of these five positions suggests strongly that no one position is likely to elicit authoritative legal consensus-ever. This literature also provides strong reason to believe that, except in the clearest cut case-namely, the requirement of congressional authorization for "the massive use of force against an enemy capable . . . of marshaling substantial force"19 - the judiciary will never enter into this debate significantly.

In a way, what is most striking about this entire body of literature, however, is that, despite the disparate legal conclusions proffered, these authors exhibit very little disagreement about what is at stake, from the point of view of sound decision-making process, in the allocation of military decision-making authority. According to the prevailing wisdom, what Congress can bring to the process of decision making with regard to the deployment of troops is democratic legitimacy and more inclusive deliberation. What the President brings to military policy making is "effectiveness." Congress, it is supposed, can insure "broad political support in the war making process,"21 while the executive can bring to bear its advantages in speed, expertise, access to confidential information, and coherence. ${ }^{22}$ On their face, every one of these procedural at-

17. Jane E. Stromseth, Understanding Constitutional War Powers Today: Why Methodology Matters, 106 YALE LJ. 845, 882 (1996) (reviewing FISHER, supra note 3.)

18. Id. at 885-86.

19. Spiro, supra note 14 , at 1348 .

20. See Stromseth, supra note 17 , at 858 .

21. Gary Born, Review Essay: The President's War Powers, 23 TEX. INT'L L.J. 153, 163. See also, e.g., Stromseth, supra note 17, at 887; Lobel, supra note 4, at 73; ELY, supra note 2 , at 4 .

22. See Born, supra note 21, at 163; Peter J. Spiro, Old Wars/New Wars, 37 WM. \& MARY L. REV. 723, 725 (1996) (reviewing FISHER, supra note 3, and WILlIAM C. BANKS \& Peter Raven-Hansen, National Securtty LaW aND the Power of the PURSE (1994)); Eugene V. Rostow, Great Cases Make Bad Law: The War Powers Act, 50 TEX. L. REV. 833, 844 (1972). 
tributes would seem to be an important part of sound governmental decision making in the military arena. But, according to the conventional wisdom, it is an unfortunate institutional reality that the allocation of power to the President or to Congress necessitates trading off among these virtues. In delineating the respective powers of the legislative and executive branches, we allegedly have to trade off decision making that is representative against decision making that is skilled. ${ }^{23}$

To understand the practical stakes of war powers debates in these terms, however, is simply inaccurate, at least with respect to a very important set of cases. That is, there is every reason to believe that, with regard to prolonged commitments of military force to hostile encounters, the executive branch is likely to engage in very poor decision making unless Congress has been brought fully "on board" with regard to the policy-making process. And, to prove the point, one could hardly imagine a more compelling testament than Robert S. McNamara's 1995 memoir of his life as Secretary of Defense, In Retrospect: The Tragedy and Lessons of Vietnam. The executive branch decision making that McNamara portrays was slow, sloppy, ill-informed, and in some respects incoherent. A more vigorous assertion of congressional influence could not possibly have made things worse-and might well have made things better. The choice we faced as a nation was not between checks and balances and effectiveness, but between checks and balances and the truly terrible policy making we endured.

Part I below reviews the McNamara memoir and its demonstration of the ineffectiveness of uni-branch military policy making, at least under particular conditions. Part II will consider why the pathologies of Vietnam War decision making are not likely to be unique-that is, why the realities of executive branch organization

23. Another "value" that Congress was intended to contribute to military policy making is its relative slowness, as compared to the executive, in making decisions to go to war. See ELY, supra note 2, at 3-4. The legislature, Madison supposed, would be less interested than the executive in making war, and, as Justice Story later observed, a large legislative body would be slower to decide for war than the more efficiently constructed executive branch. The problem, however, with using these arguments to determine an allocation of military policy making power between Congress and the executive is that these arguments still leave "war" undefined. If, on these grounds, we read the Constitution as requiring congressional authorization for any non-emergency deployment of United States troops-for the reason, that is, that any such deployment could lead to war-then it is hard to see why Congress would not have to authorize preliminarily any executive foreign affairs move, whether or not involving troops, that could precipitate war. As far as I know, there is no support for such an argument. 
and its decision-making process are likely to re-create those pathologies when Congress is only tenuously involved in resolving the most basic policy questions regarding military engagement. Part III will argue that, if I am right about the dynamics of policy making, then the values of sound military decision-making process are actually well served by preserving a state of ambiguity as to the allocation of military decision-making authority in all but the easiest cases. I conclude by arguing that, from this perspective, the War Powers Resolution is not a failure, but a success.

\section{MCNAMARA'S WAR: THE FAILURES OF EXECUTIVE POLICY MAKING}

The rhetoric of presidentialism with regard to military decision making and foreign policy generally portrays the executive branch as a lean, mean policy making machine. The President, as one person, can supposedly coordinate decisional processes and insure policy coherence in ways that a 535-member legislature cannot. He has access to confidential information, and knows how to keep a secret. He can make decisions quickly. He can marshal expertise.

Much of McNamara's rhetoric harkens wistfully-and more than a little ironically-to this ideal. He seems to measure his failures by the imagined distance he and his colleagues fell short of a heady brand of self-confident, hard-nosed, expert decision making by brilliant men (and I do not here use that last noun generically). But this is an ideal of decision making that, by McNamara's account, was nowhere realized during the Vietnam years. Every key decision that McNamara recounts belies the ideal's implicit arrogance. Indeed, conceit among key decision makers, McNamara prima inter pares, contributed mightily to the tragic sequence of events they helped sustain.

The decision-making processes described by McNamara were consistently, and with horrible results, ill-informed, shallow, hostile to genuine debate, unwilling to confront uncertainties about basic issues, and driven more by wishful thinking and by perceived political momentum than by sound interpretations of fact. This was a pattern forged early in the Kennedy Administration. Throughout meetings in the Fall of 1961 among himself, President Kennedy, and Secretary of State Rusk concerning how to respond to increasing guerilla infiltration from North into South Vietnam, McNamara waffled in trying to decide whether to support sending more advisers, equipment, and even combat troops to Vietnam. He first sug- 
gested his endorsement, and then, in combination with Rusk, withdrew it. "Looking back," he writes, "at the record of those [1961] meetings, it is clear our analysis was nowhere near adequate. We failed to ask the ... most basic questions. . ."24 In explanation, McNamara cites his inexperience, naïveté, the sheer number of problems clamoring for attention, and an unwillingness to confront in a deep way "problems for which there were no ready, or good, answers."25 None of this, except inexperience, was to change over an eight-year period.

The President's access to confidential information availed key decision makers little in the quest for sound decision making. According to McNamara, "None of us--not me, not the president, not Mac (Bundy), nor Dean, nor Max (Taylor)—was ever satisfied with the information we got from Vietnam."26 The inadequacy of written reports from both the military and from our embassy in Vietnam led the Kennedy Administration to stage special consultative meetings in Hawaii at the headquarters of the United States military commander of the Pacific. There, McNamara and others "would listen to a long series of briefings."27 But the results were not much better: "The crowded atmosphere and agenda often made it hard to focus on the issues at hand and ensure we were receiving candid reports and thoughtful recommendations."28 McNamara defends the meetings only in conclusory terms: "I believe we would have been far worse off if the meetings had not been held." ${ }^{29}$ But, based on the details of his reporting, a larger number of meetings would have yielded chiefly a larger volume of unfocussed discussions, misleading reports, and shallow recommendations.

The problem of misinformation was multidimensional. The South Vietnamese tended to relay to the United States only information that they perceived the Americans wanted to hear. ${ }^{30}$ Then, American military commanders tended to put their own spin on that information, affected both by "wishful thinking" and by mis-

24. ROBERT S. MCNAMARA, IN RETROSPECT: THE TRAGEDY AND LESSONS OF VIETNAM 39 (1995).

25. Id. at $39-40$.

26. Id. at 43 .

27. Id.

28. Id.

29. MCNAMARA, supra note 24 , at 44 .

30. See id. at 47. 
judgment as to the complexity of evaluating military success in a guerilla war. ${ }^{31}$

The pace of decision making was also a problem. Key decisions were often delayed because of persistent disagreements within the Administration over central issues. Once momentum for a decision developed, reluctant participants could find themselves going along without ever forcing real debate on the persisting points of doubt. This was tragically evident in the Kennedy Administration's handling of the unraveling Diem Administration in South Vietnam. Given Kennedy's premise that the war could not be won except by the South Vietnamese themselves, the destabilization of the Diem regime by Buddhist protests and Diem's violent retaliation might well have counseled an immediate withdrawal. No such decision was made, however, because key advisers within the Administration could not bring themselves to consensus. ${ }^{32}$

Instead, what ensued was a chaotic, even bizarre decisional process about whether to support the toppling of Diem through a military coup. In McNamara's account, our action to set the coup in motion began with a cable from Under Secretary of State for Far Eastern Affairs Roger Hilsman, Jr. to the new United States ambassador in Saigon, Henry Cabot Lodge, $\mathrm{Jr}^{33}$ The draft cable was sent to President Kennedy in Hyannis who said he would agree to transmitting the cable "if his senior advisers concurred."34 According to McNamara:

George (Ball) immediately telephoned Dean Rusk in New York and told him the president agreed. Dean endorsed it, though he was unenthusiastic. Averell (Harriman, undersecretary of state for political affairs), meanwhile, sought clearance from the CIA. Since (Director) John McCone was absent, he talked to Richard Helms, the deputy director for plans. Helms was reluctant, but, like Rusk, went along because the President had already done so. ${ }^{35}$

Further rounds of such "clearance" occurred, everyone signing on because of an assumption that everybody else, and, most important, the President, had already done so:

\footnotetext{
31. Id. at 48 .

32. See id. at 50 .

33. See id. at 52 .

34. MCNAMARA, supra note 24 , at 53.

35. Id.
} 
[Even though key advisers were] deeply divided over the wisdom of (Diem's) removal; no careful examination and evaluation of alternatives to Diem had been made by me or others; no high-level approach to Diem-with appropriate carrots and sticks-had been attempted to persuade him to mend his ways. Moreover, we allowed the controversy concerning the status of Diem to overshadow de Gaulle's proposal (to see neutralization in Vietnam). We never did give it the consideration it deserved. ${ }^{36}$

McNamara repeats his indictment of the quality of decisionmaking process regarding Vietnam in connection with virtually every important policy determination made from 1961 until his exit from government in 1968. With regard to the neutralization option, the United States position was "replete with inconsistencies and incongruities." "Br "Before authorizing the coup against Diem, we had failed to confront the basic issues in Vietnam that ultimately led to his overthrow, and we continued to ignore them after his removal." ${ }^{38}$

After Kennedy's assassination, it was left to Lyndon Johnson to decide what course to take and, especially, to decide whether to introduce significant numbers of United States combat troops into Vietnam. According to McNamara, LBJ allowed the Joint Chiefs of Staff to avoid answering key questions about the advisability of military involvement: "We never carefully debated what U.S. force would ultimately be required, what our chances of success would be, or what the political, military, financial, and human costs would be if we provided [the direct application of U.S. military force]. ${ }^{339}$ During 1964, LBJ refrained from a major build-up, but he ordered the development of military plans and asked that a resolution be drafted to give "congressional validation of expanded U.S. military action in Indochina., ${ }^{40}$

Executive decision making again did not distinguish itself in 1965 when the Administration initiated the definitive escalation of American involvement in the war. Johnson accepted the decision to bomb North Vietnam because the weakening government in Saigon

\footnotetext{
36. Id. at 55 .

37. Id. at 62 .

38. Id. at 70 .

39. MCNAMARA, supra note 24 , at 107.

40. Id. at 120 .
} 
looked too fragile to pursue any effective course of action without the United States, and no obvious alternative to bombing existed. ${ }^{41}$ Once bombing began, however, protecting United States airbases from the Viet Cong became a bootstrap argument for escalating the introduction of ground troops. ${ }^{42}$ LBJ convened a working group to review the key options, but it was rife with disagreement: "(Their) presentation to the President was full of holes." ${ }^{\text {"3 }}$ The group again "failed to confront . . . basic questions."

As debates persisted over the proper course of action, Johnson "brought to Washington a bipartisan group of elder statesmen who became known as the Wise Men (sic) ... an impressive group with knowledge, experience, and prestige." ${ }^{345}$ Unfortunately, of course, their knowledge was even less complete than that of official policy makers. Their military advice to Johnson was keyed more to ideological predisposition than analysis of fact, and LBJ altogether ignored their political advice to be far more candid with the American public. ${ }^{46}$ Two years later, when LBJ reconvened the group for further advice, he even went so far as to disinvite those "wise men" who had decided they disagreed with LBJ's policy."

McNamara properly judges harshly the results of so much inward-looking deliberation. Our policies were shaped by "loose assumptions, unasked questions, and thin analyses." 48 We were driven by a geopolitical assessment of China that was "totally incorrect." within the administration on [the] fundamental issue" of accepting a coalition government as a way to end the war. ${ }^{50}$

Contrary to the myth of the unitary executive, the hierarchical structure of executive authority did not promote well coordinated policy making or implementation. According to McNamara, a key part of the problem of shoddy decision making in connection with the Diem coup was that Dean Rusk "failed utterly to manage the

\footnotetext{
41. See id. at 171.

42. See id. at 174-77.

43. Id. at 162.

44. MCNAMARA, supra note 24 , at 162.

45. Id. at 196.

46. See id. at 197-98.

47. See id. at 306.

48. Id. at 203.

49. MCNAMARA, supra note 24, at 219 .

50. Id. at 300 .
} 
State Department and to supervise Lodge." ${ }^{\text {51 }}$ As for resolving profound disagreements within the military, military leaders "never fully debated their differences in strategic approach, or discussed them with [the Secretary of Defense] in any detail. As Secretary of Defense, I should have forced them to do both." 52 McNamara sums up the executive's performance as a coordinated entity as follows:

Underlying many ... errors lay our failure to organize the top echelons of the executive branch to deal effectively with the extraordinarily complex range of political and military issues, involving the great risks and costs-including, above all else, loss of life-associated with the application of military force under substantial constraints over a long period of time..$^{53}$

Of course, it did not help that LBJ was denying his advisers key information, such as a report from the former director of the socalled Navy Vietnam Appraisal Group that military victory was impossible, and CIA Director Richard Helms' analysis that the dangers for United States national security and foreign policy of unilateral disengagement from Vietnam were limited. ${ }^{54}$

In retrospect, McNamara seems clear as to the key process failure that led to such disastrous decision making: "We failed to draw Congress and the American people into a full and frank discussion and debate of the pros and cons of a large-scale military involvement in Southeast Asia before we initiated the action."ss As a result, it was not only the case that fundamental issues went unexamined, but also that no firm basis of public support was ever created to sustain the Administration's policy: $:^{56}$

There is no "right" moment to obtain popular consent for military action through a vote of Congress. Debate will always arise over how and when to do so. The fact is it must be done-even if a divisive vote risks giving aid and comfort to our adversary. We did not do it, and we would learn the hard way that a government must accept that risk

51. Id. at 70 .

52. Id. at 243 .

53. Id. at 323.

54. MCNAMARA, supra note 24 , at 306-07.

55. Id. at 322 .

56. See id. at $266,269$. 
in order to lead a united country into war and maintain support. Instead of working toward unity, we chose to sweep the debate under the Oval Office carpet. ${ }^{57}$

As a result, the decision making that McNamara describes misjudged the "geopolitical intentions" of our adversaries, misperceived the motivations of the leaders of South Vietnam, underestimated the importance of nationalism as a force driving the Viet Cong effort, and exaggerated the likely benefits to be realized from our superior equipment and fire power. ${ }^{58}$

\section{Why Vietnam Could Happen Again}

The sobering lessons of Robert McNamara's account would be chiefly of historical interest if the decision-making flaws he reveals could be dismissed as idiosyncrasies of particular people and unique circumstances. Such is probably not the case. McNamara identified at least seven obstacles to sound executive branch policymaking process that were of key significance at various points throughout the Vietnam debacle:

(1) Inexperience among key decision makers;

(2) An agenda overloaded with crises and difficult problems;

(3) An unwillingness to confront key assumptions;

(4) Reliance upon inaccurate information from non-United States sources;

(5) An unwillingness to confront profound disagreements among key policy makers;

(6) Peer pressure to "clear" controversial decisions; and

(7) Hostility to dissent.

Unfortunately, it is easy enough to imagine routine circumstances that would unleash these identical forces in future episodes of military decision making. The most serious of them, moreover, are likely to occur or to be costliest when one or both of the following circumstances is present: the United States engagement in a military action is of long duration and the executive feels compelled to insulate itself from potential congressional criticism with regard to the President's handling of a military initiative. 
The factor of "inexperience" is self-explanatory. Although Presidents, Secretaries of State and of Defense, and Directors of Central Intelligence may come to their respective roles with impressive training, it is unlikely that there is anything like "being there" to enable these key figures to comprehend fully the demands of their respective roles. (Even if relevant agencies are staffed with knowledgeable career personnel, the principal officer is likely to be surrounded predominantly by other political appointees.) During World War II, for example, Robert McNamara gained some presumably valuable first-hand exposure to military management through three years of work in the Army Air Corps Statistical Control Program. ${ }^{59}$ For fourteen years thereafter, he rose successfully through management ranks to become President of Ford Motor Company. ${ }^{60}$ None of this, it seems fair to say, prepared McNamara to deal with problems of such logistical and geopolitical complexity as those entailed in running the Pentagon - and as much is likely to be true for any new Secretary of Defense. (On the contrary, McNamara was probably ill-served by his experience in the sense that he was indoctrinated to believe that military policy making, even in a guerilla war, could be reduced to frameworks appropriate for purely logistical business management. ${ }^{61}$ ) In terms of policy expertise, key congressional leaders will always have an experience edge on any new executive Administration.

"Agenda overload," similarly, will be a fact of life for any Administration. But, it is most likely to be a problem for military decision making when a military deployment extends for a significant period of time. With respect to what Professor Spiro calls "strike operations," the crisis that is precipitating potential military deployment is likely to be the agenda item that briefly drives ev-

\footnotetext{
59. See MCNAMARA, supra note 24 , at $8-9$.

60. See id. at 10-13.

61. McNamara writes:
}

I insisted we try to measure progress. As I have emphasized, since my years at Harvard, I had gone by the rule that it is not enough to conceive of an objective and a plan to carry it out; you must monitor the plan to determine whether you are achieving the objective. If you discover you are not, you either revise the plan or change the objective. I was convinced that, while we might not be able to track something as unambiguous as a front line, we could find variables that would indicate our success or failure. So we measured the targets destroyed in the North, the traffic down the Ho Chi Minh Trail, the number of captives, the weapons seized, the enemy body count, and so on.

Id. at 238. 
erything else off the President's screen. That circumstance, however, cannot be indulged for more than a matter of weeks, if that long. After that, as other matters clamor for a Secretary's or for a President's attention, there will be a profoundly felt need to shrink the range of facts or issues under debate, to treat decisions already made as beyond rethinking, and, in general, to economize in one's concentration on any particular item. It should not be surprising, therefore, that, as an operation drags out, important decisions will often be made on the basis of decision makers' shallow analyses.

This dynamic, of course, will reinforce another bureaucratic behavior that will always exist-an unwillingness to revisit key assumptions. Precisely because the Presidency is so singular and visible a political target, ${ }^{62}$ there will be a built-in tendency not to rethink key commitments, lest the President, as an individual, appear to be weak, indecisive, irresolute, or unprincipled. It would have been politically very difficult for President Johnson to have said something like, "We have reviewed our initial assumption that the imperial ambitions of the Chinese Communists make it imperative to restrain North Vietnamese aggression, and we have changed our mind." The longer a President becomes invested in any foreign policy objective, the harder any such statement will become.

Note, moreover, how much harder it would likely be to revisit key assumptions when Congress has never become fully engaged in the deliberative process. In the event that a President seeks to revisit the basis for action that both elected branches have genuinely supported, his capacity to persuade Congress of their joint initial error will diffuse the political costs of changing course. If, however, the President chose to "go it alone" with respect to the fundamental choices underlying a foreign or military policy initiative, Congress can provide him no equivalent political cover.

Decision makers rarely, if ever, can count on information that is completely reliable. Even reliable information demands interpretation, which can be contested. The longer any enterprise persists, the more opportunities for inaccurate information will arise. The problem again will be intensified if Congress is not part of the policy-making process. If non-United States sources understand that the executive, but not Congress, is committed to an initiative on

62. For an important argument as to how the Presidency's "singularity" and "visibility" increase the vulnerability of the office, see Michael A. Fitts, The Paradox of Power in the Modern State: Why a Unitary, Centralized Presidency May Not Exhibit Effective or Legitimate Leadership, 144 U. PA. L. REV. 827 (1996). 
which foreign parties are relying, the temptation will loom large to skew the information presented to United States intelligence agencies, and Congress will not be afforded the capacity to provide an independent check on the reliability of that information. Moreover, the executive will want to believe information presented to it that confirms the rationality of decisions already made. There will be too much political cost associated with being wrong.

If Congress and the executive do not share in a policy commitment, Congress's skepticism may also contribute to a siege mentality within the executive that will make it hard for administrators to confront profound disagreements among key executive policy makers, no matter how persistent those disagreements. Largely to avoid paralyzing the President through indecision, key actors in the Vietnam saga managed for years to paper over their differences or to make compromises that ultimately rendered our policy incoherent. The national security team LBJ inherited from the Kennedy Administration was "deeply split over Vietnam." ${ }^{33}$ As of fall, 1964, there was a "substantial split" among LBJ's military advisers as to whether or not to launch immediate air strikes against North Vietnam. Although all the armed services endorsed the air war by February, 1965, the Army and Navy were far more pessimistic than were the Marines and Air Force about what air strikes could likely accomplish. ${ }^{64}$ Similar disagreements later surfaced concerning the number of ground troops who ought to be committed to the war effort. ${ }^{65}$ None of these conflicts was ever allowed to crystallize genuine public debate over the fundamental underlying issues.

The pressure to go forward, to leave doubts unexpressed and differences unresolved, intensifies another decision-making trait that is to some extent a universal characteristic of executive branch policy making-a desire in each decision maker not to be the "hold-out" in making a decision to which others appear committed. Life is easily made uncomfortable for the person perceived as an obstructionist in the path of accomplishing a presidential objective, especially an objective as seemingly unambiguous as prevailing over a clear adversary. The momentum behind the cable that precipitated Diem's overthrow dramatically illustrates the tendency. McNamara characterizes most of the decision makers as signing on

\footnotetext{
63. MCNAMARA, supra note 24 , at 101.

64. See id. at 175.

65. See id. at 192-94.
} 
reluctantly to a decision that each assumed had, for all intents and purposes, already been made, and none was sufficiently adventurous to delay. ${ }^{66}$

The ubiquitous bureaucratic inclination toward "group think," exacerbated by the other factors just outlined, is also likely to manifest itself in a hostility to the expression of dissent within the executive. Dissent not only casts doubt on early decisional commitments, but it takes up everyone's time and calls into question advice earlier rendered-and the advisers who rendered it. McNamara details in his memoir how unresponsively key decision makers responded to George Ball's arguments in 1964 and in 1965: first, that the Administration should pursue more aggressively a political resolution to the Vietnam impasse, ${ }^{67}$ and, second, that it should seriously limit its further deployment of ground troops to Vietnam. ${ }^{68}$ Understandably, McNamara's own deepening conviction in 1967 that the United States should withdraw from Vietnam rendered his continued leadership of the Pentagon untenable. ${ }^{69}$

It is entirely possible that the tragedies of Vietnam, both for that country and for ours, could have been drastically curtailed had the executive branch undertaken a more genuine policy making partnership with Congress. LBJ was determined, instead, to prevent well-informed public debate about his Vietnam objectives and plans. He never publicly stated the singularity of his goal to win the war, or, as McNamara puts it, the absence of any plan in 1964 to accomplish that objective. ${ }^{70} \mathrm{He}$ withheld information about the degree to which the United States escalated the air war in $1965 .{ }^{11}$ He failed to keep his 1964 promise to consult Congress closely in the wake of the Gulf of Tonkin resolution. ${ }^{72} \mathrm{He}$ made no public statement regarding the extraordinary fiscal implications of the intensified war effort. ${ }^{73}$

Had the executive branch been amenable to more serious congressional involvement in the development of Vietnam policy, it would have been able to take advantage of the foreign policy experience of senior members of Congress. At least some such mem-

\footnotetext{
66. See id. at 52-55.

67. See id. at 156.

68. See MCNAMARA, supra note 24 , at 192-93.

69. See id. at 273-314.

70. See id. at 148.

71. See id. at 172 .

72. See id. at $138,180$.

73. See MCNAMARA, supra note 24 , at 205.
} 
bers could have provided a sustained focus on Vietnam, even as the executive struggled with other foreign and domestic policy crises. Members of Congress would have felt freer than the President's subordinates to test the key assumptions underlying United States policy, and to challenge the quality of information used to inform United States decision making. Disagreements among policy makers would have been aired earlier, and greater caution would have been exercised in making controversial decisions.

A more open process would have been more receptive to the views of those within Congress who would have counseled restraint. As early as December, 1963, Senate Majority Leader Mike Mansfield urged LBJ to pursue the neutralization of Vietnam as a politically acceptable result. ${ }^{74}$ Senator Wayne Morse was an early and persistent critic of the war, whose views could have helped catalyze a deeper debate within Congress had the relevant facts not been concealed by the Johnson Administration. ${ }^{75}$ Senator Mansfield opposed the buildup of troops in $1965,{ }^{76}$ as did Senator Russell, who urged the President to withdraw in light of the deeply divided public view of the wisdom of a troop buildup. ${ }^{77}$ LBJ never cooperated in fashioning an interbranch dialogue that would have had to grapple with these views held by powerful Senators.

To observe this, however, is also to observe that the most important question, from the standpoint of the national interest, is not whether any particular military foray is formally lawful. After all, Congress provided sufficient authorization for virtually every aspect of the Vietnam War to address all constitutional requirements. What the national interest demands in any truly sustained military effort is an ongoing congressional counterweight to the pressures within the executive to avoid asking hard questions, to cover up differences, to leave convenient information unexamined and conceal inconvenient information, and to leave ambiguous, even inconsistent objectives untested by analysis. That depends on a depth of interbranch consultation that simply did not exist during the Vietnam period.

74. See id. at 106.

75. See id. at $118,136$.

76. See id. at 191.

77. See id. at 190 . 


\section{THE WAR POWERS RESOlUtion, INTERBRANCH DECISION MAKING AND THE RULE OF LAW}

For those who believe in the rule of law, there is likely to be much appeal in the work of John Hart Ely, Louis Fisher, and Jules Lobel, on one hand, or of Robert Turner and John Yoo on the other. That is because each of these sets of war powers scholars has argued for an interpretation of the Constitution's allocation of military authority that amounts to a bright-line rule. Implementing any of their interpretations would make government legality or illegality easy to spot; such is the advantage of clear rules for operationalizing the rule of law.

In 1987, however, writing about the dynamics of interbranch executive privilege contests, I noted the difficulty of adhering to this model of the "rule of law" in settings in which Congress and the President may legitimately entertain substantially different interpretations of their constitutional obligations. There are contexts, of which the war powers controversy is perhaps the paradigm example, (1) in which each elected branch, following conventional methods of legal interpretation, may legitimately understand the requirements of separation of powers law very differently, and (2) in which, for a variety of legal and institutional reasons, it is unlikely that courts will ever intervene substantially. ${ }^{78}$ That is, there will not be any institutionally designated umpire to announce the "one right answer" to the major constitutional questions presented. In such settings, it is far from obvious how best to implement constitutional law as a serious constraint on arbitrary political judgment and as a source of genuine accountability to principled norms.

In such contexts, I argued that each elected branch, rather than conceptualizing interbranch disputes as occasions to prevail in the imposition of its legal views on the other, should accept that, to some extent, each branch enjoys a "jurisdiction within which it is permitted to interpret the Constitution independently." 79 In such settings, the rule of law is best served if both legislative and executive lawyers seek to articulate for their respective branches a conscientious interpretation of the Constitution, faithful to the "kinds of interpretive methods that characterize the legal culture

78. See Peter M. Shane, Legal Disagreement and Negotiation in a Government of Laws: The Case of Executive Privilege Claims Against Congress, 71 MiNN. L. REv. 461, 466-70 (1987).

79. Id. at 470 . 
generally. ${ }^{180}$ It is no affront to the rule of law if the articulated doctrines of the elected branches conflict, so long as each branch takes seriously its responsibility to formulate a coherent legal doctrine that accommodates "its particular institutional interests within a legal framework that is justifiable under conventional, legitimate forms of legal reasoning." ${ }^{81}$ If a conflict in the legal doctrines of the respective elected branches poses difficulty in the resolution of a particular dispute, then Congress and the President should undertake a problem solving approach that allows each branch to uphold its sense of institutional obligation without attempting to resolve the underlying legal disagreements in a definitive way. ${ }^{82}$ It is through such a process, I argued, that the elected branches are most likely to exhibit the commitments to accountability and mutual restraint that the rule of law demands.

There are, to be sure, some knotty issues to be confronted in this approach. For instance, how shall we comprehend the possibility that Congress can evolve legal doctrine other than through the enactment of statutes or that the executive can generate law other than through statutorily authorized rulemaking or adjudication? My suggestion, following upon an important article by Michael Glennon, ${ }^{83}$ was that custom could be a source of law in separation of powers disputes. In particular, making an analogy to norm formation in the context of international law, I argued that an elected branch's "doctrine" of executive privilege law could be discerned from its behavior in particular disputes. ${ }^{84}$

In 1995, then-Yale Law student Christopher Ford adopted an identical approach in analyzing the post-Vietnam evolution of war powers law. ${ }^{85}$ It is clear that, since the enactment of the War Powers Resolution ${ }^{86}$ ("WPR") the executive branch has often resisted technical compliance with its formal textual commands. From this point of view, the WPR has failed as law. And yet, as Ford points out, if one reviews the actual behavior of the two branches,

80. Id. at 496.

81. Id. at 541 .

82. See id. at 497.

83. See Michael Glennon, The Use of Custom in Resolving Separation of Powers Disputes, 64 B.U. L. REv, 109 (1984).

84. See Shane, supra note 78 , at 478.

85. See Christopher A. Ford, War Powers as We Live Them: Congressional-Executive Bargaining Under the Shadow of the War Powers Resolution, 11 J.L. \& PoL. 609, 613620 (1995).

86. 50 U.S.C. $\S \S 1541-48$ (1994). 
it is clear that they have achieved a modus vivendi, an "effective law" of war powers that balances a de facto legislative delegation of "strike operation" discretion to the executive against a significantly constraining process within which the executive must proceed if it is intent on any lengthy or massive military deployment. The WPR has supported, in other words, an interbranch dynamic that has made each branch more accountable to its institutional obligations.

The WPR embodies three key commands to the executive. In committing United States military forces to hostilities or to situations in which hostilities may be imminent, the executive must: (1) consult Congress to the extent practicable, ${ }^{87}$ (2) report within forty-eight hours of the relevant commitment, ${ }^{88}$ and (3) withdraw within sixty or ninety days, if Congress does not affirmatively authorize the military deployment. ${ }^{89}$

For military operations intended to take but a few days to execute, the WPR essentially leaves the President to his own discretion. President Reagan's invasion of Grenada and bombing of Libya, President Bush's invasion of Panama, and President Clinton's bombing of Iraq and expedition to Haiti exemplify such operations. In none of these cases did the President acknowledge that he was legally bound by the WPR. Nonetheless, in each of these cases, the President did make a report to Congress within 48 hours of the commencement of the operation-just as the WPR would require..$^{90}$

In contrast, the WPR explicitly asserts Congress's entitlement to decide whether the United States should go to war or place itself on a war footing. Again, although President Bush denied his need for legislative authorization, the fact that he sought explicit congressional authority for Operation Desert Storm paid obvious respect to Congress's understanding of its own powers. He did not seriously seek to deny that the deployment of tens of thousands of American troops in defense against what was then believed to be a genuinely powerful military adversary implicated Congress's war

\section{7. $\S 1542$.}

88. $\S 1543(a)$

89. § $1544(\mathrm{~b})$.

90. See Ford, supra note 85, at 664 (Grenada), 668 (Panama); United States Air Strike Against Libya, 1986 PUB. PAPERS 499 (Libya); Letter to Congressional Leaders on the Strike on Iraqi Intelligence Headquarters, 29 WEEKLY COMP. PRES. DOC. 1183 (1993) (Iraq); Letter to Congressional Leaders on Haiti, 30 WeEkLY COMP. PRES. Doc. 1823 (1994) (Haiti). 
policy prerogatives. ${ }^{91}$ Moreover, despite what must surely have been the temptation to do otherwise, President Bush eventually did not order United States troops to seek the overthrow of Saddam Hussein-which would have gone beyond the scope of Congress's authorizing resolution. ${ }^{92}$

Between the various brief post-Vietnam "strikes" and our one full-scale war, the United States has also entered into a number of more ambiguous deployments-most notably, in Lebanon, Somalia, and Bosnia. In each case, an American President initiated a deployment on his own discretion, and then negotiated with Congress over the degree to which the deployment would be governed by express statutory constraint. ${ }^{93}$ In the case of Lebanon, Congress went so far as to enact the only statute that has yet purported formally to implement the WPR, providing a fixed period of authorization of United States troops to remain in Lebanon. ${ }^{94}$

Interpreting these events, John Hart Ely and Louis Fisher find little evidence that Congress has recaptured its constitutional prerogatives. ${ }^{95}$ Dean Ely clearly regards as a sham Congress's purported efforts to "restrain" the executive under the WPR. And, indeed, there is probably a compelling case to be made that the invasion of Panama, in particular, was a violation of international law. ${ }^{96}$

As for our own constitutional law, however, the picture does not seem to Mr. Ford or to me to be anywhere so bleak. Despite the executive's recurring broad claims of unilateral discretion, it has, in fact, comported with Congress's dictates. ${ }^{97}$ President Bush did not go to war without congressional approval. In all cases, Presidents have reported to Congress, as required.

It is true, of course, that various Presidents engaged in strike operations without advance congressional approval. What is not clear, however, is that Congress adheres to a view of the Constitution that renders such operations unlawful. Although Congress has

91. See Ford, supra note 85 , at 669-78.

92. See Authorization for use of Military Force Against Iraq Resolution, Pub. L. 10201, 105 Stat. 3 (1991).

93. See Ford, supra note 85 , at $630-62$ (Lebanon), 678-700 (Somalia); SHANE \& BRUFF, supra note 1, at 841-42, and FISHER, supra note 3, at 157-61 (Bosnia).

94. See Multinational Force in Lebanon Resolution, Pub. L. 98-119, 97 Stat. 805 (1983).

95. See FISHER, supra note 3, at xi-xiii; ELY, supra note 2, at 49.

96. See FISHER, supra note 3, at 146-47.

97. Dr. Fisher does not disagree with this conclusion. See id. at 133. 
never ceded to the President any formal acknowledgement of constitutionally based executive discretion in such endeavors, Congress has routinely tolerated strike operations-correctly perceiving that they pose no genuine threat to Congress's capacity to regulate more substantial forms of military deployment.

As for Lebanon, Somalia, and Bosnia, it seems clear that each of the elected branches used the ambiguity of its own powers-and the ambiguity of the legal status of our military deployments-to help leverage its bargaining position over the course of events. A less vigilant Congress-the Congress of the 1960 s, for example-could easily have allowed any of these engagements to become a version of Vietnam. In each case, however, Congress used the WPR and its own claims to authority to force the executive to sharpen its articulation of American objectives, respond to contrary positions with regard to the executive branch's foreign policy analyses, and share substantial information with Congress. In every case, the country experienced a better informed and more substantial intragovernment debate over military policy than the executive mustered in the Vietnam era. In the cases of Lebanon and Somalia, Congress helped set the stage for a relatively early withdrawal of ground troops. In the case of Bosnia, congressional pressure presumably helped curtail what might have been a temptation to commit United States ground troops even prior to the Dayton accords. With the Dayton accords in place, the United States deployment had a far better defined mission than would have been the case had the Clinton Administration moved earlier in that direction. It also seems to be a mission that the American people accepts.

In the post-Vietnam era, Congress has become a more vigorous participant in foreign military policy making. ${ }^{98}$ The pattern is unmistakable. That does not mean executive decision making has consistently become wise. But, in nearly all cases, it has complied with a system of accountability and justification that accords as well with our rule of law ideals as one might reasonably hope in a context not refereed by courts. Without the WPR, it might have been a much harder system to sustain.

If the process were now to be reformed, it seems unlikely that the key improvement needed is a requirement of formal congressional approval prior to strike operations. What we need is a genuine congressional commitment after strike operations to an intensive 
and independent factual post-mortem regarding every military deployment. The knowledge that Congress is reliably committed to such investigations would help assure that, in planning even strike operations, the executive branch would truly confront and question the key assumptions underlying its proposed initiatives, test the information available to it, force key executive policy makers to address seriously the disagreements among them, and engage in intrabranch debate sufficiently open and receptive to dissent to merit public confidence in the decisions ultimately reached.

Of course, from at least one substantive point of view this version of the rule of law is truly disappointing. If you believe that strike operation deployments of American military power are virtually never going to serve the interests of international justice, then the process I would permit will seem an insufficient constraint on American militarism. But conflating the goals of legality and sound policy is, especially in this context, a mistake. There is apparently a substantial consensus within Congress that the current "exigencies of life . . . demand some degree of executive and military flexibility." 99 In the face of such consensus, although law is a form of politics, it is not a form of politics plausibly sufficient to protect the world against improper assertions of American force. That is what elections are for.

In short, for those military engagements that are unambiguously "war," the WPR has effectively affirmed Congress's authority to authorize or to forbear from military hostilities. In other deployments that portend lengthy and dangerous commitments of United States troops, the WPR has created a framework for interbranch negotiation that has helped to assure Congress a more significant role in the regulation of military force. In strike operations, the WPR has effectively delegated discretion to the executive, but it is in these cases that the costs of Vietnam-style policy making pathology loom least. Congress can reduce even these costs by investigating such operations closely after the fact. Through such investigations, Congress would more effectively be asserting what it believes to be the primacy of its authority without formally denying the executive a degree of discretion that, if experience is any guide, Congress wants the President to have.

99. Ford, supra note 85 , at 703. 


\section{CONCLUSION}

What many war powers scholars yearn for-a consensus, bright-line understanding of the constitutional allocation of military policy making authority-is unlikely ever to occur. Congress and the President approach the relevant task of constitutional interpretation with too many conflicting interests at stake, and courts are unlikely to intervene seriously. That does not render such scholarship uninformative or even unpersuasive. It does mean, however, that it is harder to jump from such analyses to an authoritative conclusion that some executive military initiative is plainly lawful or unlawful.

From the standpoint of the American polity, there exists, moreover, an inquiry into the history of any military deployment that may be more pressing than, "Did Congress sufficiently authorize it?" That more urgent question is whether Congress was sufficiently engaged in the policy making process to minimize the risks of shallow, incoherent, self-indulgent policy making from which we and the Vietnamese suffered so terribly during the Vietnam War.

If we are to understand what the "rule of law" demands in the war powers context, I would argue, therefore, that we should seek a legal theory that supports a form of interbranch interaction that maximizes the potential for serious interbranch deliberation and mutual accountability. The War Powers Resolution creates a framework supportive of that kind of dynamic. ${ }^{100}$ Over time, under the WPR regime, a pattern of interbranch accommodation may become so stable that the President and Congress will be seen to have evolved a joint conception of the relevant law, which the judiciary, if it ever does involve itself in these issues, is most likely to uphold. That's fine. Constitutional law may be generated by actors other than courts. Moreover, constraints other than law will always be necessary to make sure our substantive decisions on military deployment are wise.

\footnotetext{
100. Indeed, it provides in the war powers context what I have argued is precisely the central element missing in executive privilege disputes, which would be necessary to sustain a constructive problem-solving dynamic (i.e., a set of written understandings within which a modus vivendi can be implemented. See generally Peter M. Shane, Negotiating for Knowledge: Administrative Responses to Congressional Demands for Information, 44 ADMIN. L. REV. 197 (1992)).
} 